\title{
Knowledge transfer and cross-border acquisition performance: the impact of cultural distance and employee retention
}

Article

Accepted Version

Creative Commons: Attribution-Noncommercial-No Derivative Works 4.0

Ahammad, M. F., Tarba, S. Y., Liu, Y. and Glaister, K. W. (2016) Knowledge transfer and cross-border acquisition performance: the impact of cultural distance and employee retention. International Business Review, 25 (1). pp. 66-75. ISSN 0969-5931 doi:

https://doi.org/10.1016/j.ibusrev.2014.06.015 Available at https://centaur.reading.ac.uk/81842/

It is advisable to refer to the publisher's version if you intend to cite from the work. See Guidance on citing.

To link to this article DOI: http://dx.doi.org/10.1016/j.ibusrev.2014.06.015

Publisher: Elsevier

All outputs in CentAUR are protected by Intellectual Property Rights law, including copyright law. Copyright and IPR is retained by the creators or other copyright holders. Terms and conditions for use of this material are defined in the End User Agreement. 


\section{CentAUR}

Central Archive at the University of Reading

Reading's research outputs online 
Knowledge Transfer and Cross-Border Acquisition Performance:

The Effect of Cultural Distance and Employee Retention

Mohammad Faisal Ahammad ${ }^{a}{ }^{*}$, Shlomo Yedidia Tarbab, Yipeng Liuc, Keith W. Glaister ${ }^{\text {d }}$

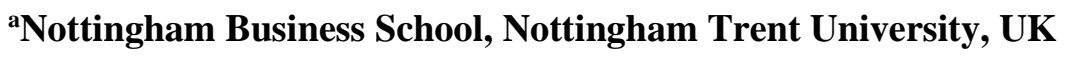

${ }^{b}$ Management School, The University of Sheffield, UK

'Kent Business School, The University of Kent, UK

${ }^{d}$ Warwick Business School, University of Warwick, UK 


\begin{abstract}
The current understanding of when and how knowledge transfer leads to cross-border acquisition (CBA) success is still limited. The aims of the paper are to provide new insights into the factors that facilitate or impede knowledge transfer, and to examine the impact of knowledge transfer on CBA performance. The data were gathered via a cross-sectional survey using a questionnaire on a sample of UK firms that had acquired North American and European firms. The findings indicate that knowledge transfer and employee retention have positive influence on CBA performance. In addition, organizational culture differences have a negative influence on CBA performance, but also mediate the relationship between knowledge transfer and CBA performance. No direct or mediating effect of national cultural distance has been found on knowledge transfer and CBA performance. One of the important contributions of the present paper is the development of a conceptual framework incorporating the mediating effect of national cultural distance, organizational culture differences, and employee retention on knowledge transfer and acquisition performance. Moreover, we have tested the two distinct types of knowledge transfer namely knowledge transfer in the functional area and knowledge transfer in the general management area, thus making a contribution to the existing literature on knowledge transfer in CBAs.
\end{abstract}

Keywords: Cross-border acquisition, Employee retention, Knowledge transfer, National cultural distance, Organizational culture differences, Performance 


\section{INTRODUCTION}

The exploration of cross-cultural differences in merger and acquisition (M\&A) has yielded inconsistent and perplexing findings (Gomes, Angwin, Weber, and Tarba, 2013; Gomes, Weber, Brown, \& Tarba, 2011; Teerikangas \& Very, 2006; Weber \& Tarba, 2012; Weber, Tarba, \& Reichel, 2009; 2011). Several studies conducted in the last two decades show that cultural differences have a negative effect on M\&A performance, but other studies have explicitly indicated that cross-cultural differences affect both negatively and positively M\&A performance (e.g., Ahammad \& Glaister, 2011a; 2011b; Reus \& Lamont, 2009; Sarala \& Vaara, 2010; Slangen, 2006; Vaara, Sarala, Stahl, \& Björkman, 2011; Weber, Tarba, \& Rozen-Bachar, 2011; Weber, Tarba, Stahl, \& Rozen Bachar, 2012).

Strategy researchers have begun to examine knowledge transfer processes during acquisition implementation. Previous studies have delineated several mechanisms facilitating knowledge transfer, such as social community (Bresman, Birkinshaw, \& Nobel, 1999, 2010), culture and socialization as a learning strategy (Zander \& Zander, 2010), and dominant logic perspective (Verbeke, 2010). However, the current understanding of when and how knowledge transfer leads to CBA success is limited.

The objectives of the present study are to pinpoint the role that knowledge transfer plays in cross-border acquisition performance, and to elucidate the impact of employee retention, national cultural distance, and organizational culture differences on knowledge transfer and acquisition performance. Furthermore, our study aims to shed light on the factors that facilitate or hamper knowledge transfer. In this way, we intend to develop a better understanding of the parameters that make the knowledge transfer process successful in the context of the cross-border mergers 
and acquisitions thus contributing to better understanding of added value creation process and synergy realization in international M\&A.

We begin by reviewing the literature on knowledge transfer, national cultural distance and organizational (corporate) culture differences, and employee retention in $\mathrm{M} \& \mathrm{~A}$, and to develop our hypotheses. Next, we explain the research design and method adopted for the study. Finally, we present and discuss the results of the study and conclude with its theoretical and managerial implications.

\section{LITERATURE REVIEW AND HYPOTHESES}

\section{Knowledge transfer in $M \& A$}

Knowledge transfer is critically important for value creation, both for the acquirer and for the target of a cross-border M\&A (Birkinshaw, Bresman, \& Håkanson, 2002; Sarala, Junni, Copper, and Tarba, 2014). According to Ranft and Lord (2002), knowledge transfer, that is, the acquisition and utilization of new sets of knowledge-based resources, is one of the primary objectives of mergers and acquisitions, and plays a significant role in the process of synergy realization in acquisitions (Junni, 2011). Previous studies have delineated several mechanisms facilitating knowledge transfer, such as social community (Bresman, Birkinshaw, \& Nobel, 1999, 2010), culture and socialization as a learning strategy (Zander \& Zander, 2010), and dominant logic perspective (Verbeke, 2010).

Knowledge-based view of firms as knowledge generators and integrators (Grant, 1996a; Kogut \& Zander, 1992). The ability of a firm to create value hinges largely on sets of intangible, knowledge-based resources (Leonard, 1998; Nonaka, 1994). Firms can achieve higher than average performance if they have relatively idiosyncratic and non-substitutable organizational 
knowledge that can be used for added value creation (Almor, Tarba, \& Benjamini, 2009; Junni and Sarala, 2011; 2012; Ranft, 2006). Although knowledge is highly valuable and it may help the focal organization achieve competitive advantage, gaining knowledge by virtue of crossborder acquisition is a challenging task, and consequently the process can result in as many problems as benefits (Junni, Sarala, and Vaara, 2013; Lakshman, 2011; Oberg and Tarba, 2013; Ranft, 2006).

As indicated by Nelson and Winter (1982), explicit knowledge can be articulated, codified, and accessed by means of verbal communication and written documents. A firm can access new knowledge by acquiring it (Ahuja \& Katila, 2001) or by grafting the knowledge of other firms onto their own (Huber, 1991). For instance, Zou and Ghauri (2008) found that the process of knowledge transfer and learning is conducive to performance improvement of international acquisitions.

According to Sternberg and Horvath (1999), tacit knowledge is grounded in personal experience, and it is procedural rather than declarative in structure. Although tacit knowledge is difficult to formulate and codify, several studies found that it significantly affects organizational performance (Nonaka \& Takeuchi, 1995; Prahalad \& Hamel, 1990). The acquisition of tacit knowledge is affected by learning styles; for example, effective experiential learning is found to facilitate the knowledge acquisition process (Armstrong \& Mahmud, 2008). In the context of cross-border acquisition (CBA), social interactions between acquiring and target firms may establish a venue for channelling tacit knowledge at a collective level, such as joint tasks or projects, so that tacit knowledge transfer can have a positive effect on acquisition performance.

Extending prior research, we hypothesize that:

Hypothesis 1: Knowledge transfer has a positive effect on CBA performance. 


\section{Organizational culture differences}

Organizational culture differences affect post-merger integration and performance Weber, 1996; Weber, Shenkar, \& Raveh, 1996; Weber and Tarba, 2012). The meta-analysis conducted by Stahl and Voigt (2008) points to the fact that cultural differences affect socio-cultural integration and synergy realization, and increase shareholder value. Social and operational integration mechanisms are conducive to the post-acquisition transfer of capabilities (Bjorkman, Stahl, \& Vaara, 2007). Moreover, various cultural integration mechanisms, such as communication (Schweiger \& Denisi, 1991; Weber and Tarba, 2010) and use of expatriates (Hebert, Very, \& Beamish, 2005), can be effective means for overcoming the cultural distance between the amalgamating entities. The influence of corporate culture differences and other human resourcerelated factors on the effectiveness of the post-acquisition integration is complex and varies across different industry sectors (Weber, 1996; Weber and Fried; 2011a;2011b; Weber et al., 1996). Several research studies advanced our understandings of the effects of national and organizational culture differences and of post-acquisition integration mechanisms (Sarala, 2010; Sarala \& Vaara, 2010). For example, Sarala (2010) indicated that organizational culture differences increase post-acquisition conflicts, which can lead to inferior post-acquisition performance. Although corporate culture analysis can alleviate the tension between the acquiring and target firms during the M\&A process (Weber and Tarba, 2011;2012; Weber, Tarba, and Rozen Bachar, 2011; 2012), we argue that organizational culture distance cannot be easily overcome. Hence:

Hypothesis 2: Organizational culture differences have a negative effect on CBA performance.

\section{National cultural distance}


Chakrabarti, Gupta-Mukherjee, \& Jayaraman, (2009) have found that acquisitions performance is better in the long run if the acquirer and the target come from countries that are culturally more disparate. They also indicate that overall national cultural distance rather than dimensionwise differences seems to drive these results, albeit the difference in masculinity appears to hurt performance slightly, presumably due to integration-related problems.

Reus and Lamont (2009) indicate that national cultural distance impedes understandability of key capabilities that need to be transferred, and constrains communication between acquirers and their acquired units, thus having a negative indirect effect on the acquisition performance.

Slangen (2006) showed that the planned level of post-acquisition integration moderates the relationship between national cultural distance and acquisition performance. National cultural distance has a negative impact on acquisition performance at high levels of planned integration, and a positive impact at low levels.

Uhlenbruck (2004) reached the conclusion that national cultural distance reduces the extent to which acquirers learn from experiences abroad and impedes the sales growth of acquired firms. Hofstede's $(1980 ; 2001)$ national culture values framework has been used in a variety of studies in management and psychology (Kirkman, Lowe, \& Gibson, 2006). The relationship between national cultural distance and CBA performance remains a puzzle, with some studies pointing to positive effects and others highlighting the negative ones (Rottig, Reus, and Tarba, 2013). In his explorative study of cross-border mergers and acquisitions, Angwin (2001) reached the conclusion that national cultural distance plays an important role in affecting the acquirer's perceptions of target companies, which in turn affect post-acquisition performance. Other scholars have confirmed that the post-integration mode plays an important role in the effect of national culture distance on CBA performance. The specific dimension of national culture can help in elucidating the post-acquisition integration approach and subsequent post-acquisition 
performance (Liu \& Woywode, 2013; Morosini, Shane, \& Singh, 1998; Sarala \& Vaara, 2010; Weber, Tarba, \& Rozen Bachar, 2011).

National cultural distance can prompt learning in the context of CBAs because differences in beliefs, values, and practices have the potential to promote learning and innovation (Barkema \& Vermeulen, 1998; Vermeulen \& Barkema, 2001). Holtbrügge \& Mohr (2010) on their part showed that national culture values affect the learning style preferences of individuals . We argue, therefore, that national culture distance can serve as an opportunity for both the acquirer and target firms to complement each other in comprehending and leveraging cultural resources in order to bring about a positive outcome for the CBA. We, therefore, hypothesize that:

\section{Hypothesis 3: National culture distance has a positive effect on CBA performance.}

\section{Employee retention}

Several studies have shown that turnover intention of managers at the acquired firms is higher than at firms not engaged in acquisitions (Cannella \& Hambrick, 1993; Krug \& Hegarty, 1997, 2001). Walsh (1988) reported that in the first year after acquisition, 25\% of top managers left the company, and only $40 \%$ of top managers stayed with the acquired company five years after acquisition. Buchholtz et al. (2003) investigated top management turnover and reported that about $75 \%$ of top managers left the company by the end of the third year after acquisition. Consistent with previous research, in a longitudinal study, Krug (2003) found that average turnover rates among senior management was significantly higher in the acquired firms than in non-acquired entities, and was highest in the first and second years after the acquisition. In the same vein, Bergh (2001) explored the association between target company executive retention and the probability of target firm divesture, and found that target firms with the highest probability of divesture are the ones with the fewest incumbent executives retained. Moreover, the acquired firms least likely to be divested succeeded most in retaining their executives. 
According to Cannella and Hambrick (1993), managers are an integral part of the acquired company's resource foundation, and therefore one of the significant determinants of acquisition success is the retention of acquired firm employees. Thus, the success of the acquisition can depend largely on the retention of employees, their skills, and knowledge (Ahammad, Glaister, Weber, and Tarba, 2012; Krug, Wright, \& Kroll, 2014; Walsh and Ellwood, 1991).

When the value of the acquisition is generated by leveraging the knowledge present in human capital of the target firm, it is crucial to avoid the turnover of key staff (Ranft \& Lord, 2002). Previous studies suggest that top management turnover in M\&As has important implications for post-acquisition performance (Hambrick \& Cannella Jr, 1993; Walsh, 1989). An employee retention plan can lower CEO resistance to takeover (Buchholtz \& Ribbens, 1994).

Post-acquisition integration, which includes coordination between the two firms engaged in the acquisition, is considered to be one of the most important factors in realizing the synergistic benefits of the M\&A (Larsson \& Finkelstein, 1999; Larsson \& Lubatkin, 2001). Employee retention is an essential component in successful integration management (Gomes, Weber, Brown, \& Tarba, 2011; Weber et al., 2011b). Although human resources (HR) practices such as training, communication, and autonomy are important to M\&A performance, there is no clear best practice to address the cross-cultural conflict situation that can arise in CBAs (Weber, Rachman-Moore, \& Tarba, 2011a; Weber \& Tarba, 2010). Weber and Tarba (2010) suggest that acquiring companies should use HR practices to develop integration capabilities during the postacquisition phase in order to improve M\&A performance.

Post-acquisition integration is influenced by the national institutional environment, which includes the complex legal and labor market arrangements in different countries (Capron \& 
Guillen, 2009). If employees of the target firm perceive positively the employee retention policy and the potential for job creation in the amalgamated company, CBAs performance can improve.

Hypothesis 4: Employee retention has a positive effect on CBA performance.

\section{The mediating effect of national cultural distance and organizational culture differences on knowledge transfer}

According to the knowledge-based view of business performance, organizations function as devices that assist in the transfer of knowledge through the development of combinative and absorptive capabilities (Junni and Sarala, 2013; Reus, 2012). National culture distance between the acquiring and target firms create complementary capabilities that may result in performance variation (Morosini, Shane, \& Singh, 1998). Absorptive capacity at the individual and organization levels determines the degree of knowledge transfer (Zahra \& George, 2002). As defined by Cohen and Levinthal (1990), absorptive capacity is the ability of a company to recognize valuable external information, assimilate it, and eventually apply it to commercial ends. Absorptive or learning capacity facilitates the absorption and use of external knowledge and enables organizations to identify strategic opportunities that can serve as a basis for innovation (Volberda, Foss, \& Lyles, 2010). Organizational absorptive capacity depends not only on the sum of individual absorptive capacities but also on organizational aspects, such as organizational culture.

The cornerstone of the process-based view of absorptive capacity is the organization's stock of prior knowledge, which is at the basis of the knowledge flow within the organization (Lane, Koka, \& Pathak, 2006). Furthermore, as highlighted by Weber \& Tarba (2011), Weber, Tarba, \& Oberg (2014), and Weber, Tarba, Stahl, \& Rozen Bachar (2012) the combinative competences, namely organizational processes by which firms acquire and synthesize knowledge resources in order to realize the synergy potential, are of utmost importance for M\&A success. Jansen, Van 
Den Bosch, and Volberda (2005) pointed out on their part that potential absorptive capacity, which contains the elements of knowledge acquisition and assimilation, is enhanced by such coordination capabilities as cross-functional interfaces and job rotation, whereas realized absorptive capacity, which contains the elements of knowledge transformation and assimilation, is enhanced by socialization competences.

In this study we subscribe to the argument that both national cultural distance and organizational culture differences affect absorptive capacity (Vaara, Sarala, Stahl, \& Björkman, 2012). In the case of international acquisitions, the prospect of the acquired firm providing a distinct set of routines and capabilities enhances in the presence of national cultural distance (Morosini, Shane, $\&$ Singh, 1998). Such capabilities and routines are different from those of the acquiring firm and cannot be readily replicated in the home country. Likewise, the acquiring firm can offer distinct capabilities and expertise to the acquired firm, which are not easily imitated in the host country of the acquired firm. Thus, cultural distance assists in the formation of a richer bundle of knowledge-based resources that are causally more ambiguous and socially more complex. Moreover, significant national cultural distance and organizational culture differences assist in the formation of knowledge-based resources and encourages the transfer of knowledge in the combined firm, helping create a competitive advantage. Thus, knowledge-based resources enhance the competitive advantage of combined firm, and improve post-acquisition performance in the long term. We argue, therefore, that both national and organizational culture mediates the relationship between knowledge transfer and CBA success.

Hypothesis 5: Organizational culture differences mediates the relationship between knowledge transfer and CBA performance.

Hypothesis 6: National culture distance mediates the relationship between knowledge transfer and CBA performance. 


\section{The mediating effect of employee retention on knowledge transfer}

Several studies (Cannella \& Hambrick, 1993; Hambrick \& Cannella, 1993; Lubatkin, Schweiger, \& Weber, 1999; Zollo \& Singh, 1998) contend that the departure of incumbent senior management from acquired companies has a negative effect on M\&A performance because of the severe disruptions caused by uncertainty, organizational conflicts, and the loss of key talent at the acquired firms. Other studies (Ernst \& Vitt, 2000; Ranft, 2006; Ranft \& Lord, 2000; 2002) also provide corroborative evidence that high turnover can adversely affect M\&A performance.

Ranft and Lord (2000) maintain that retention of key employees is a prerequisite for the successful appropriation of competences by the acquiring firm. Employee retention is essential for preserving the knowledge embedded in the acquired firm and for transferring it to the newly combined firm. Tacit knowledge is difficult to articulate and codify; it is primarily "acquired by and stored within individuals in highly specialized form" (Grant 1996a, p. 385). Employee retention may have important bearing on knowledge transfer because individuals who have special knowledge are critical for the sustainable competitive advantage of the firm. A study based on 75 high-tech acquisitions indicates that extensive communication and preservation of key employees is conducive to transfer of knowledge in acquisitions (Ranft, 2006). Prior acquisition experience influences acquisition performance (Zollo \& Singh, 2004). If we consider acquisition experience as a type of knowledge, it is possible to argue that key employee can affect knowledge transfer from prior acquisitions to the focal deal. From a transfer theory perspective, Ellis, Reus, Lamont, \& Ranft (2011) suggested that retaining acquired top managers in large related acquisitions can help acquirers assemble experiences from smaller related acquisitions. Consequently, the knowledge transfer effect on CBA performance might be eliminated by the absence of key employee retention. By contrast, a study based on grounded 
qualitative research argues that greater autonomy granted to the target firm may inhibit the transfer of acquired firm's technologies and capabilities inherent in its tacit knowledge (Ranft \& Lord, 2002).

Therefore, we formulate the following hypothesis:

Hypothesis 7: Employee retention mediates the relationship between knowledge transfer and CBA performance.

The conceptual framework of the study is shown in Figure 1. Consistent with prior research, we suggest that knowledge transfer, cultural distance, and employee retention can directly affect the performance of CBAs. In addition, we propose that cultural distance and employee retention can mediate the relationship between knowledge transfer and CBA performance.

Insert Figure 1 about here

\section{METHODOLOGY}

We used a questionnaire survey to collect data from a sample of UK firms involved in CBA. Acquisitions by UK firms took place between 2000 and 2004 among firms operating in Europe and North America. A list of potential UK acquiring firms was compiled from the Thomson One Banker Database. A list of potential survey participants was collected using telephone enquiries and a website search. These procedures produced an initial sample of 798 UK firms involved in CBA. Two hundred and seven firms were eliminated because the managers were busy, unable to participate in the survey, or the company had no policy for participating in questionnaire surveys.

The survey was carried out in 2007. A total of 591 questionnaires were sent to UK executives involved in acquiring foreign firms. To encourage accurate responses, participants were assured of anonymity. After three reminders, 69 questionnaires were returned by participants. Four 
questionnaires were not fully completed and were discarded. A total of 65 questionnaires were usable, resulting in a response rate of $11 \%$, which can be considered satisfactory.

We carefully selected the statistical tests used based on the sample size. According to Preacher and Hayes (2008), bootstrapping can be helpful for small sample sizes, especially when assumptions of normality cannot be met in testing indirect effects or mediating effect. Our study involves indirect effects and a small sample size. Therefore, we selected SPSS multiple mediation with bootstrapping.

We were not able to achieve a higher response rate for two reasons. First, collecting responses from top executives is extremely difficult, as indicated by Harzing (1997). Second, Cycyota and Harrison (2006) noted a decreasing trend in response rates involving top executives over the years. Our response rate is consistent with that reported in other studies involving top executives. For example, Mukherjee, Kiymaz, and Baker (2004) were successful in obtaining a response rate of 11.8\% from 636 Chief Financial Officers (CFOs) engaged in managing acquisitions. Graham and Harvey (2001) obtained a response rate of around 9\% from CFOs.

Participants in the survey were actively engaged in the decision-making process of CBAs. Twelve of the respondents were Chief Executive Officers, 16 were CFOs or Finance Directors, 23 were Business Development Directors, 8 were Managing Directors and 6 were Executive Directors. Thirty five CBAs took place in Europe and 30 in North America. The target country and industry distribution of the sample are shown in Tables 1 and 2.

Insert Table 1 about here

Insert Table 2 about here 


\section{Addressing common method bias, retrospective bias, and non-response bias}

From each company a single participant provided data on independent variables, dependent variables, and the control variables. Therefore, the data may suffer from common method bias. The likelihood of such a bias is low, however, because performance, organizational culture distance, national culture distance, knowledge transfer, and employee retention were measured by a large number of questionnaire items, and the contents of these constructs were dissimilar. Moreover, to minimize common method bias, provisions were made against priming effect and consistency following the suggestion of Podsakoff et al. (2003). We also checked for common method bias by conducting Harman's single-factor test (Podsakoff et al., 2003). When the independent and dependent variables of the study were included, the un-rotated factor analysis produced 4 factors. $29.05 \%$ of the total variance was explained by the largest factor. The findings of Harman's test indicate an absence of severe common method variance. Finally, the probability of common method variance effects was low because of the low likelihood of complex relationships involving the mediating effect of cultural distance on knowledge transfer among variables that are unlikely to be part of the participants' cognitive map (Chang et al., 2010).

The possibility of retrospective bias was assessed by comparing key descriptive variables from acquisitions conducted in 2004 with those conducted in 2000. The t-tests for mean differences were statistically insignificant, suggesting a low likelihood of retrospective bias.

Consistent with Ranft and Lord (2000), two tests were conducted to check the possibility of nonresponse bias. First, early respondents were compared with late respondents with respect to key descriptive variables. Second, non-respondents were compared with respondents along several key descriptive variables such as primary sector of operation and relative size. The mean differences were not significant in t-tests, suggesting an absence of systematic bias. 


\section{Measurement of Variables}

\section{Dependent variable: $\mathrm{CBA}$ performance}

Following Schoenberg (2004), acquisition performance was measured based on nine items: Return on sales, Sales growth, Share price, Growth of market share, Cash flow, Asset utilization, Earnings per share, Return on investment, and Profitability. Respondents were asked to indicate their answers on a 5-point Likert scale ranging from $1=$ Expectation not met to $5=$ Expectation fully met. Respondents also indicated the weight of each performance measure on a 5-point Likert scale ranging from $1=$ Not important to $5=$ Very important. A composite measure of performance was estimated as follows:

$$
\text { Performance }_{\mathrm{a}}=\sum_{s=\mathbf{1}}^{9} P s W s
$$

where Performance ${ }_{\mathrm{a}}=$ Performance of acquisition $\mathrm{a}, \mathrm{Ws}=$ the weight of type $s$ performance, and Ps $=$ the type $s$ performance of the acquisition.

Respondents were also asked to indicate Overall success on a 5-point Likert scale ranging from $1=$ Not successful to $5=$ Very successful. The correlation between overall success and the composite measure of performance was positive and strong. In the subsequent analysis, the composite measure of performance was used.

\section{Independent variables}

\section{Knowledge transfer}

Consistent with Schoenberg (2004), knowledge transfer was determined by requesting participants to specify the degree to which knowledge had been transmitted from and to the 
acquired firm after completion of the acquisition in the following 11 areas: Product and service design, R\&D, Service/manufacturing operations, Purchasing/supplier relation, Distribution /outlets, Personnel/HRM, Marketing and sales, Strategic planning, Customer service, Investment appraisal, and Financial reporting. Respondents were asked to specify the degree to which gains based on transferring skills had been achieved on 5-point Likert scale ranging from $1=$ No skill transfer to $5=$ Significant skill transfer.

An attempt was made to identify a parsimonious set of variables to determine the underlying dimensions governing the full set of 11 measures of knowledge transfer. Exploratory factor analysis (EFA) using varimax rotation was used to extract the underlying factors. EFA generated two non-overlapping factors, explaining a total of $69 \%$ of the observed variance. By averaging the scores for the items that loaded on each factor, we calculated an overall score for each of the factors generated by EFA. As each measure seems to tap into a different category of knowledge transfer, we used both measures. Factor $1(\alpha=0.87)$ was labeled Knowledge transfer Functional areas and factor $2(\alpha=0.83)$ was labeled Knowledge transfer - General management.

\section{National culture distance}

We calculated the national culture distance based on the practice scores of the nine dimensions of the GLOBE project (House et al., 2004). Consistent with the formula used by Morosini, Shane, and Singh (1998), we calculated an index for national culture distance. The formula we used was:

$$
C D_{j}=\sqrt{\sum\left(I_{i j}-I_{i k}\right)^{2}}
$$

Where:

$C D_{j}=$ the cultural differences for the $j$ th country, $I_{i j}=$ the GLOBE score for $i$ th cultural dimension and the $j$ th country, and $k=\mathrm{UK}$. 


\section{Organizational culture differences}

Organizational culture difference was measured using four items adapted from previous studies (Chatterjee et al., 1992; Datta, 1991). Participants were asked to measure the degree to which the acquired foreign firm diverged from the acquiring firm in (a) values, beliefs, and philosophy, (b) general management style, (c) approach to risk taking, and (d) reward and evaluation systems. For the four measures of organizational culture differences, EFA generated one factor explaining a total of $70.69 \%$ of the observed variance. We calculated a composite measure of organizational culture distance by averaging the scores.

\section{Employee retention}

Consistent with Ranft and Lord (2000), we asked respondents to specify the importance of retaining employees of the acquired firm in the following positions: (a) top management, (b) middle management, (c) manufacturing and operations, (d) R\&D, and (e) finance, legal, and other staff. For each of the above position, respondents were asked to indicate the extent of importance on a 5-point Likert scale ranging from $1=$ Not important to $5=$ Extremely important. Respondents were also asked to indicate the extent of employee retention from the acquired firm one year after acquisition on a 5-point Likert scale ranging from $1=$ No retention to $5=$ Full retention. We calculated a composite measure of employee retention by multiplying the scores of retention with those of importance.

\section{Control variables}

Four control variables were included in the analysis. Relative size was assessed by asking the key informant to rate the size ratio (by sales) of the acquired firm and the acquiring firm before 
the acquisition. Relative performance was measured by asking respondents to indicate the profitability of the acquired foreign firm compared to that of the acquiring firm at the time of acquisition on a 5-point Likert scale ranging from $1=$ Very poor to $5=$ Very good. Acquisition relatedness was measured by including a variable where 1 indicates acquisition in the same industry and 0 indicates acquisition in a different industry. Respondents were asked to indicate the extent of acquisition experience on a 5-point Likert scale ranging from $1=$ No experience to $5=$ Great experience

\section{FINDINGS}

The survey data were screened to check for outliers, out-of-range values, and missing data by examining univariate statistics (Tabachnick \& Fidell, 1996). Table 3 shows the descriptive statistics and correlations for each of the variables used in the analyses.

Insert Table 3 about here

We used multiple mediation analysis because we have conducted both direct and indirect or mediating tests of our hypotheses (cf., Poppo, Zhou, \& Sungmin, 2008). To examine multiple mediations, we used bootstrapping that allows for non-normal sample distributions. Bootstrapping is a non-parametric resampling method. Tables 4 and 5 report the results based on Preacher and Hayes' (2008) multiple mediation SPSS macro.

Insert Table 4 about here

\section{Direct effects}

The regression results reported in Tables 4 and 5 (direct effects) show positive and significant coefficients on knowledge transfer (both functional and general management area) (Table 4: $\beta=$ 
1.404, $\mathrm{p}<0.05$; Table 5: $\beta=1.607, \mathrm{p}<0.05)$. This finding confirms a significant direct effect of knowledge transfer on CBA performance, which supports hypothesis 1.

According to Tables 4 and 5 (direct effects), the regression confirms the negative and significant coefficients on organizational culture differences (Table 4: $\beta=-1.205, \mathrm{p}<0.05$; Table 5: $\beta=-1.405, \mathrm{p}<0.05)$. This suggests a significant negative effect of organizational culture differences on CBA success, which is consistent with hypothesis 2 .

As reported in Tables 4 and 5 (direct effects), the regression results demonstrate that the coefficients on national cultural distance are positive, but are not significant (Table $4: \beta=1.383$, $\mathrm{p}>0.10$; Table 5: $\beta=0.824, \mathrm{p}>0.10$ ), offering no support for hypothesis 3 .

Insert Table 5 about here

Hypothesis 4 predicted a positive relationship between employee retention and CBA success. The findings indicate a positive and significant coefficient on employee retention in the knowledge transfer - functional area regression model (Table 4: $\beta=0.167, p<0.10$ ). By contrast, the coefficient on employee retention is positive but not significant in the knowledge transfer - general management regression model (Table 5: $\beta=0.037, p>0.10$ ). Thus, we found moderate support for hypothesis 4 .

Considering the control variables, acquisition relatedness is not significant. Prior acquisition experience is negatively associated with acquisition performance, but it is significant only in the knowledge transfer - functional area model (Table 4). There is a positive and significant relationship between the prior profitability of the target firm and CBA success. 


\section{Mediating effects}

As shown in Table 4 (indirect effects), the multiple mediation findings confirm a significant estimate of organizational culture differences and knowledge transfer - functional area (Table 4: $\beta=0.268, \mathrm{p}<0.10)$. Moreover, bootstrap results do not contain zero in the confidence interval (CI95: $-1.15,-0.02)$, suggesting that the indirect effect is significantly different from zero. These results offer strong support for hypothesis 5. In Table 5, however, the estimate of organizational culture differences becomes insignificant (Table 5: $\beta=0.193, \mathrm{p}>0.10$ ), and the confidence interval contains zero $\left(\mathrm{CI}_{95}:-1.00,0.07\right)$. Therefore, hypothesis 5 is partially supported, but the results offer support for the view that there is a positive relationship between CBA performance and knowledge transfer through the mediating effect of organizational culture differences.

We found no support for hypothesis 6. According to Table 4 and 5, the estimate of national cultural distance is insignificant (Table 4: $\beta=-0.046, \mathrm{p}>0.10$; Table 5: $\beta=0.037, \mathrm{p}>$ 0.10), and the confidence interval includes zero (Table 4: CI95: -0.06, 0.15; Table 5: $\mathrm{CI}_{95}:-0.14$, 0.48). Therefore, hypothesis 6 was not supported.

Nor was hypothesis 7 supported. Table 4 shows a negative and significant estimate of employee retention and knowledge transfer - functional area (Table 4: $\beta=-2.039, \mathrm{p}<0.05$ ). However, the bootstrap results for employee retention include zero $\left(\mathrm{CI}_{95}:-1.17,0.02\right)$. Table 5 does not confirm a statistically significant relationship between employee retention and knowledge transfer - general management $(\beta=1.372, p>0.10)$, and the confidence interval includes zero (CI95:-0.13, 0.76).

\section{DISCUSSION}

The findings indicate that the ability of merging firms to transfer knowledge can explain a substantial portion of CBA success. Knowledge transfer remains a strong indicator of CBA success even after controlling for alternate factors affecting acquisition performance. The 
findings confirm the assumption made by several M\&A researchers (for example, Ranft, 1997; Bresman, Birkinshaw, \& Nobel, 1999) and offer strong support for the knowledge-based view of business performance.

We also shed light on the effect of national cultural distance and organizational culture differences on knowledge transfer and CBA success. As argued by Teerikangas and Very (2006), prior research on M\&As, with the exception of a few studies (Olie, 1994; Very et al., 1997), has generally considered only one level of culture: either national or corporate, in contradiction with the current trend toward a multi-level view of culture in organizational and sociological research (Teerikangas \& Very, 2006). Teerikangas and Very (2006) contended that the findings of earlier research studies differ depending on whether the object of examination was the effect of corporate (organizational) culture or of national cultural distance. The divergent findings indicate the importance of clearly differentiating the concepts of national cultural distance and organizational culture differences. In this paper we have examined national cultural distance and organizational culture differences separately. Our findings indicate that national cultural distance and organizational culture differences are dissimilar constructs because they are not significantly correlated $(r=-0.054)$. Moreover, the relationship between knowledge transfer and national cultural distance and organizational cultural differences, and the effect of organizational culture differences and national cultural distance on CBA success varied considerably. National cultural distance showed no significant effect on knowledge transfer or CBA success, but organizational culture differences showed a significant impact on knowledge transfer and a strong effect on CBA success. The findings associated with organizational culture differences are consistent with prior findings by Larsson \& Finkelstein (1999). Moreover, our results support the view of Weber, Shenkar, and Raveh (1996) and Weber, Tarba, and Reichel $(2009 ; 2011)$ that 
national cultural distance and organizational culture differences are dissimilar constructs that affect M\&A success differently.

We found no support for the direct effect of national cultural distance on CBA success. This result is similar to that of previous research, which found no support for either a positive or a negative effect on acquisition success (e.g., Barkema et al., 1996). Moreover, according to a meta-analysis, the mean effect size of the association between acquisition performance and national cultural distance approaches zero (Stahl \& Voigt, 2008). Therefore, the association between national cultural distance and CBA performance, and organizational cultural differences and CBA performance appears to be complex and multifaceted.

Earlier research suggests that studies investigating the direct effect of culture on accounting or financial measures of performance at times inadvertently ignore or omit the vital post-M\&A dynamics by focusing exclusively on the ultimate financial outcomes rather than on the entire processes that has led to these outcomes (Teerikangas \& Very, 2006; Stahl \& Vogit, 2005). Our paper examines the direct effect of national cultural distance and organizational cultural differences on CBA success, as well as of their mediating effect on knowledge transfer and CBA success. We argue that greater national cultural distance and organizational culture differences assists in creating unique knowledge-based resources and encourages firms to actively transfer these in the combined firm. Transfer of such knowledge-based resources enhances the competitive advantage of the combined firm and eventually, post-acquisition performance.

The findings of the present study provide reasonable support for the proposition (hypothesis 4) that CBA performance is directly influenced by employee retention. This finding is consistent with Cannella and Hambrick (1993), who argued that incumbent senior 
management is the critical part of the resource base of the acquired firm, and that retention of senior management is of utmost importance for improving M\&A performance. Finally, our findings are consistent with other empirical studies supporting the view that employee retention has a positive effect on M\&A performance (Bergh, 2001; Ahammad \& Glaister, 2011b).

We found no support for the mediating effects of employee retention on the knowledge transfer process (hypothesis 7). This may be explained by the fact that acquisitions are viewed as an emotional incident for employees of the acquired firm, and can have a negative effect on employee retention. The stimulating effect of employee retention on knowledge transfer has to do with the retained sets of skills and competences that we may not have been able to capture in our data analysis.

\section{CONCLUSIONS}

This paper provides an empirical examination of the effect of knowledge transfer on the success of cross border acquisitions. Earlier researchers did not consider the mediating effect of culture and employee retention in explaining the factors influencing knowledge transfer and CBA performance. Thus, one of the important contributions of the present paper is the development of a conceptual framework incorporating the mediating effect of cultural distance and employee retention on knowledge transfer and acquisition performance. Another significant contribution of the present study lies in pinpointing the specific mechanisms by which national cultural distance and organizational culture differences affect the knowledge transfer process and consequently, CBA performance. In addition, in the current study, we have tested the two types of knowledge transfer namely knowledge transfer in the functional area and knowledge transfer in the general management area, thus making a contribution to the existing literature on knowledge transfer in M\&A. 
Our study has a number of managerial implications. Firstly, knowledge transfer has a significant positive influence on CBA success. Transfer of knowledge to and from acquired firm may lead to the development of sustainable competitive advantage which, in turn, can enhance CBA performance. Therefore, manager involved in the management of CBA should provide support and resources in ensuring a smooth knowledge transfer. Secondly, our findings indicate that employee retention positively influence CBA performance. Therefore, managers should consider retaining employees of the acquired firm. Thirdly, our findings indicate that organizational culture distance has a negative impact on CBA performance. Managers should undertake steps such as organizing cultural awareness workshops in order to reduce the negative effect of organizational cultural differences on the CBA performance. Finally, the findings indicate that there is a positive relationship between knowledge transfer and CBA performance through the mediating effect of organizational culture differences. Thus, although too much differences in organizational culture may be detrimental to CBA performance, managers of the acquiring firm should also take advantage of organizational culture differences of combined firm by supporting the formation of a richer bundle of knowledge based resources from two distinct cultures and by encouraging the transfer of knowledge in the combined firm in order to create a competitive advantage which, in turn, can produce superior CBA performance. 
Figure 1. Conceptual Framework

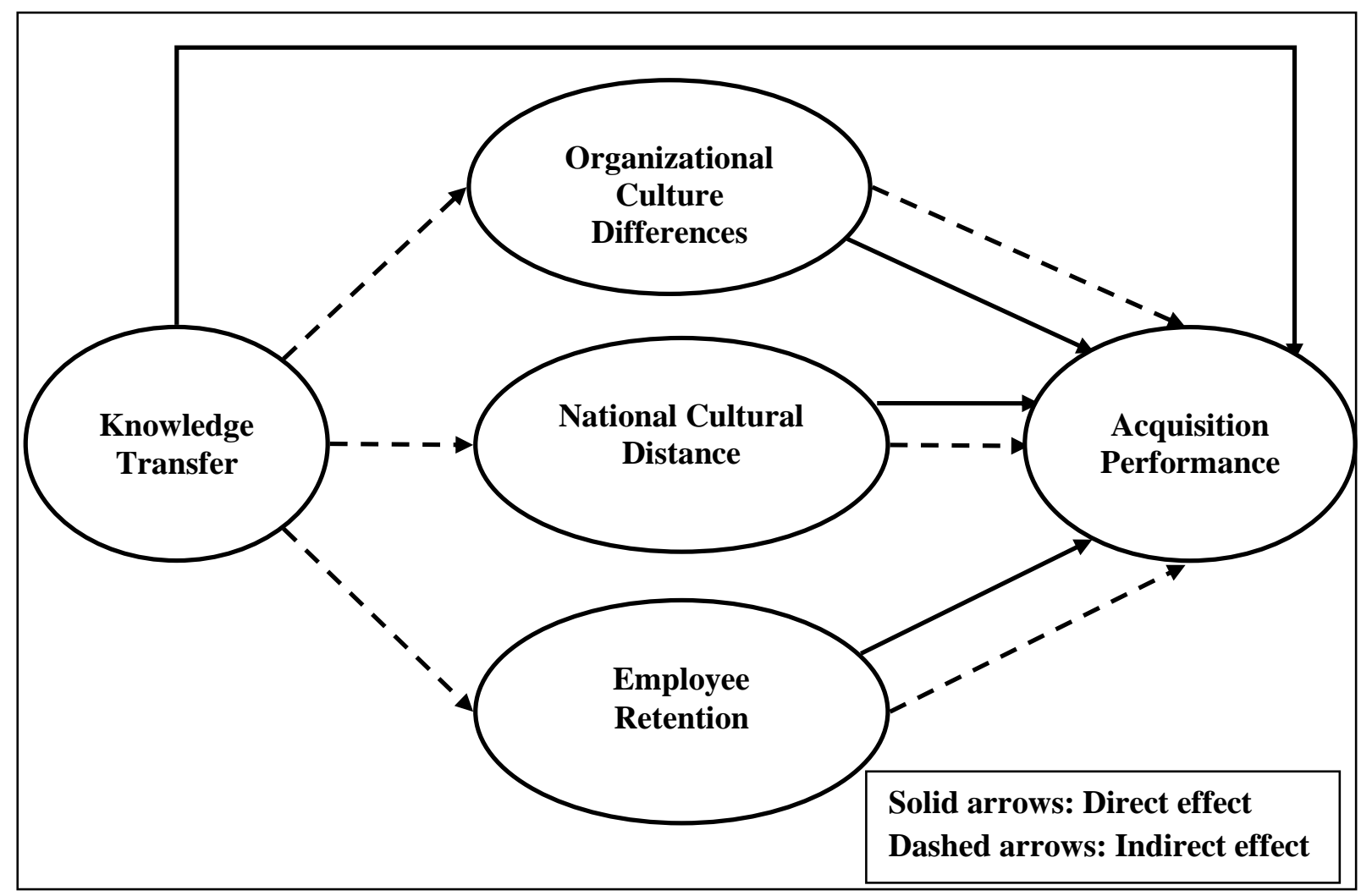


Table 1. Country and size distribution of target firms for UK cross-border acquisitions

\begin{tabular}{ccccc}
\hline Country & Frequency & Small firms & Medium firms & Large firms \\
\hline USA & 21 & 8 & 5 & 8 \\
Canada & 9 & 5 & 4 & 0 \\
Netherlands & 5 & 2 & 0 & 3 \\
Sweden & 4 & 2 & 1 & 1 \\
Germany & 9 & 3 & 1 & 5 \\
Spain & 2 & 0 & 1 & 1 \\
France & 4 & 1 & 0 & 3 \\
Belgium & 3 & 1 & 2 & 0 \\
Italy & 3 & 1 & 0 & 2 \\
Russia & 3 & 0 & 0 & 3 \\
Switzerland & 2 & 1 & 0 & 1 \\
Total & $\mathbf{6 5}$ & $\mathbf{2 4}$ & $\mathbf{1 4}$ & $\mathbf{2 7}$
\end{tabular}

Table 2. Industry distribution of sample and population for UK cross-border acquisitions

\begin{tabular}{lcc}
\hline Industry & \% of total sample & \% of total population \\
\hline Consumer products and services & 17.9 & 16.6 \\
Energy and power & 11.0 & 6.6 \\
Financial services & 5.3 & 8.9 \\
Healthcare & 4.2 & 8.1 \\
High technology & 12.8 & 16.1 \\
Industrials & 12.7 & 11.2 \\
Materials & 13.0 & 10.9 \\
Media and entertainment & 3.6 & 7.9 \\
Real estate & 1.5 & 4.3 \\
Retail & 2.1 & 5.6 \\
Consumer staples & 2.1 & 2.9 \\
Telecommunications & 13.8 & 5.2 \\
Total & $\mathbf{1 0 0 \%}$ & $\mathbf{1 0 0 \%}$
\end{tabular}




\section{Table 3. Means, standard deviations, and correlations}

\begin{tabular}{|c|c|c|c|c|c|c|c|c|c|c|c|c|}
\hline Variables & Mean & S.D. & 1 & 2 & 3 & 4 & 5 & 6 & 7 & 8 & 9 & 10 \\
\hline Profitability of the acquired firm & 3.25 & 1.16 & 1 & & & & & & & & & \\
\hline Acquisition relatedness & $\begin{array}{l}0 / 1 \\
\text { variable }\end{array}$ & 0.00 & -0.12 & 1 & & & & & & & & \\
\hline Acquiring firm's experience & 4.03 & 0.95 & $0.31 *$ & 0.12 & 1 & & & & & & & \\
\hline Relative size & 2.49 & 1.04 & $0.25 * *$ & 0.18 & 0.17 & 1 & & & & & & \\
\hline Organizational culture differences & 0 & 1.00 & $-0.32 * *$ & -0.03 & -0.04 & 0.17 & 1 & & & & & \\
\hline National cultural distance & 0 & 1.00 & 0.08 & 0.03 & 0.04 & -0.02 & -0.05 & 1 & & & & \\
\hline Employee retention & 12.19 & 5.95 & $0.29 *$ & 0.17 & 0.14 & 0.17 & -0.23 & -0.08 & 1 & & & \\
\hline Knowledge transfer - Functional area & 0 & 1.00 & -0.04 & 0.12 & 0.20 & $0.71 * *$ & $0.26 * *$ & -0.16 & -0.16 & 1 & & \\
\hline $\begin{array}{l}\text { Knowledge transfer - General } \\
\text { management area }\end{array}$ & 0 & 1.00 & $0.43 * *$ & 0.13 & -0.01 & $0.64 * *$ & -0.05 & 0.00 & $0.36^{*}$ & 0.00 & 1 & \\
\hline Acquisition performance & 12.98 & 4.87 & $0.50 * *$ & 0.06 & 0.13 & $0.55^{* *}$ & $-0.31 *$ & 0.12 & $0.34 * *$ & -0.16 & $0.36 * *$ & 1 \\
\hline
\end{tabular}


Table 4. Regression results for multiple mediations: Knowledge transfer - Functional area ${ }^{\mathrm{a}}$

\begin{tabular}{|c|c|c|c|c|}
\hline & $\begin{array}{c}\text { Control } \\
\text { variables for } \\
\text { performance } \\
\text { (Partial } \\
\text { effects) }\end{array}$ & $\begin{array}{l}\text { Mediators of } \\
\text { acquisition } \\
\text { performance } \\
\text { (Direct effects) }\end{array}$ & $\begin{array}{c}\text { Knowledge } \\
\text { transfer } \\
\text { (Functional area) } \\
\text { to mediators } \\
\text { (Indirect effects) }\end{array}$ & $\begin{array}{c}\text { Bootstrap } \\
\text { results } \\
\text { CI } \\
\text { Lower/Upper }\end{array}$ \\
\hline Relative size & 0.009 & & & \\
\hline Acquisition & & & & \\
\hline Relatedness & 1.543 & & & \\
\hline Prior experience & $-0.864^{*}$ & & & \\
\hline $\begin{array}{l}\text { Target firm } \\
\text { profitability }\end{array}$ & $1.812 * * *$ & & & \\
\hline $\begin{array}{l}\text { Organizational culture } \\
\text { differences }\end{array}$ & & $-1.205^{* *}$ & $0.268 *$ & $-1.15,-0.02$ \\
\hline $\begin{array}{l}\text { National cultural } \\
\text { distance }\end{array}$ & & 1.383 & -0.046 & $-0.06,0.15$ \\
\hline Employee retention & & $0.167 *$ & $-2.039 * *$ & $-1.17,0.02$ \\
\hline Total indirect effects & & & & $-1.88,-0.13$ \\
\hline $\begin{array}{l}\text { Knowledge transfer - } \\
\text { functional area }\end{array}$ & & $1.404^{* *}$ & & \\
\hline \multicolumn{5}{|l|}{ Model estimates for } \\
\hline \multicolumn{5}{|l|}{ DV } \\
\hline $\mathrm{R}^{2}$ & & 0.535 & & \\
\hline $\mathrm{F}$ & & $6.913 * * *$ & & \\
\hline
\end{tabular}

${ }^{a}$ Unstandardized coefficients are reported. Bootstrap results are provided for the lower and upper bounds of $95 \%$ confidence intervals. $\mathrm{N}=65 ; * \mathrm{p}<0.10 ; * * \mathrm{p}<0.05 ; * * * \mathrm{p}<0.01$ 
Table 5. Regression results for multiple mediations: Knowledge transfer - General management ${ }^{\mathrm{a}}$

\begin{tabular}{|c|c|c|c|c|}
\hline & $\begin{array}{l}\text { Control } \\
\text { variables for } \\
\text { performance } \\
\text { (Partial } \\
\text { effects) }\end{array}$ & $\begin{array}{l}\text { Mediators of } \\
\text { acquisition } \\
\text { performance } \\
\text { (Direct effects) }\end{array}$ & $\begin{array}{l}\text { Knowledge transfer } \\
\text { (General } \\
\text { management) } \\
\text { to mediators } \\
\text { (Indirect effects) }\end{array}$ & $\begin{array}{l}\text { Bootstrap } \\
\text { results } \\
\text { CI } \\
\text { Lower/Upper }\end{array}$ \\
\hline Relative size & 0.001 & & & \\
\hline Acquisition relatedness & 0.447 & & & \\
\hline Prior experience & -0.089 & & & \\
\hline Target firm profitability & $1.021 *$ & & & \\
\hline $\begin{array}{l}\text { Organizational culture } \\
\text { differences }\end{array}$ & & $-1.4057 * *$ & 0.193 & $-1.00,0.07$ \\
\hline National cultural distance & & 0.824 & 0.037 & $-0.14,0.48$ \\
\hline Employee retention & & 0.037 & 1.372 & $-0.13,0.76$ \\
\hline Total indirect effects & & & & $-0.91,0.56$ \\
\hline $\begin{array}{l}\text { Knowledge transfer - } \\
\text { general management area }\end{array}$ & & $1.607 * *$ & & \\
\hline $\mathrm{R}^{2}$ & & 0.547 & & \\
\hline $\mathrm{F}$ & & $7.261 * * *$ & & \\
\hline
\end{tabular}

${ }^{a}$ Unstandardized coefficients are reported. Bootstrap results are provided for the lower and upper bounds of $95 \%$ confidence intervals. $\mathrm{N}=65 ; * \mathrm{p}<0.10 ; * * \mathrm{p}<0.05 ; * * * \mathrm{p}<0.01$ 


\section{References:}

Ahammad, M.F., \& Glaister, K.W. (2011a). The double-edged effect of cultural distance on cross-border acquisition performance. European Journal of International Management, 5(4): $327-345$.

Ahammad, M.F., \& Glaister, K.W. (2011b). Post-acquisition management and performance of cross-border acquisitions. International Studies of Management and Organization, 41(3): 69-87.

Ahammad, F.M., Glaister K.W., Weber, Y., \& Tarba, S.Y. (2012). Top management retention in cross-border acquisitions: the roles of financial incentives, acquirer's commitment and autonomy. European Journal of International Management, 6(4): 458-480.

Ahuja, G., \& Katila, R. (2001). Technological acquisitions and the innovation performance of acquiring firms: A longitudinal study. Strategic Management Journal, 22(3): 197-220.

Almor, T., Tarba, S.Y., \& Benjamini, H. (2009). Unmasking integration challenges: The case of Biogal's acquisition by Teva Pharmaceutical Industries. International Studies of Management \& Organization, 39(3): 33-53.

Angwin, D. (2001). Mergers and acquisitions across European borders: National perspectives on preacquisition due diligence and the use of professional advisers. Journal of World Business, 36(1): 32-57.

Armstrong, S. J., \& Mahmud, A. (2008). Experiential learning and the acquisition of managerial tacit knowledge. Academy of Management Learning \& Education, 7(2): 189-208.

Barkema, H. G., \& Vermeulen, F. (1998). International expansion through start-up or acquisition: A learning perspective. Academy of Management Journal, 41(1): 7-26.

Barkema, H. G., Bell, J. H. J., \& Pennings, J. M. (1996). Foreign entry, cultural barriers and learning. Strategic Management Journal, 17(2): 151-166.

Barney, J. B. (1991). Firm resources and sustained competitive advantage. Journal of Management, 17(1): 99-120.

Bergh, D. D. (2001). Executive retention and acquisition outcomes: A test of opposing views on the influence of organizational tenure. Journal of Management, 27(5): 603-622.

Birkinshaw, J., Bresman, H., \& Håkanson, L. (2002). Managing the post-acquisition integration process: How the human integration and task integration processes interact to foster value creation. Journal of Management Studies, 37(3): 395-425.

Bjorkman, I., Stahl, G. K., \& Vaara, E. (2007). Cultural differences and capability transfer in cross-border acquisitions: the mediating roles of capability complementarity, absorptive capacity, and social integration. Journal of International Business Studies, 38(4): 658-672.

Bresman, H., Birkinshaw, J., \& Nobel, R. (1999). Knowledge transfer in international acquisitions. Journal of International Business Studies, 30(3): 439-462.

Bresman, H., Birkinshaw, J., \& Nobel, R. (2010). Knowledge transfer in international acquisitions. Journal of International Business Studies, 41(1): 5-20.

Brouthers, L. E., and Xu, K. (2002). Product stereotypes, strategy and performance satisfaction: The case of Chinese exporters. Journal of International Business Studies, 33(4): 657-677. 
Buchholtz, A. K., \& Ribbens, B. A. (1994). Role of chief executive officers in takeover resistance: Effects of CEO incentives and individual characteristics. Academy of Management Journal, 37(3): 554-579.

Buchholtz, A. K., Ribbens, B. A., \& Houle, I. T. (2003). The role of human capital in post acquisition CEO departure. Academy of Management Journal, 46(4), 506-514.

Buono, A. F., \& Bowditch, J. L. (1989). The human side of mergers and acquisitions, San Francisco: Jossey-Bass.

Calori, R., Lubatkin, M., Very, P., \& Veiga, J. F. (1997). Modelling the origins of nationallybound administrative heritage: A historical institutional analysis of French and British firms. Organization Science, 8(6), 681-696.

Cannella, A. A., \& Hambrick, D. C. (1993). Effects of executive departures on the performance of acquired firms. Strategic Management Journal, 14(S1): 137-152.

Capron, L. (1999. The long-term performance of horizontal acquisitions. Strategic Management Journal, 20(11): 987-1018.

Capron, L., \& Guillen, M. F. (2009). National corporate governance institutions and postacquisition target reorganization. Strategic Management Journal, 30(8): 803-833.

Cartwright, S, \& Cooper C. L. (1992). Mergers and acquisitions: The human factor. Oxford: Butterworth-Heinemann.

Castro, C., \& Neira, E. (2005. Knowledge transfer: analysis of three internet acquisitions. International Journal of Human Resource Management, 16(1): 120-135.

Chakrabarti, R., Gupta-Mukherjee, S., \& Jayaraman, N. (2009). Mars-Venus marriages: Culture and cross-border M\&A. Journal of International Business Studies, 40: 216-236.

Chang, S-J., van Witteloostuijn, A., \& Eden, L. (2010). From the editors: common method variance in international business research. Journal of International Business Studies, 41(2): 178-184.

Chatterjee, S., Lubatkin, M., Schweiger, D. and Weber, Y. (1992). Cultural differences and shareholder value in related mergers: Linking equity and human capital. Strategic Management Journal, 13(5): 319-334.

Cohen, W. M., \& Levinthal, D. A. (1990). Absorptive capacity: A new perspective on learning and innovation. Administrative Science Quarterly, 35(1): 128-152.

Cycyota, C. S., \& Harrison, D. A. (2006). What (not) to expect when surveying executives: A meta-analysis of top managers response rates and techniques over time. Organizational Research Method, 9(2): 133-160.

Datta, D. K. (1991). Organisational fit and acquisition performance: Effects of post-acquisition integration. Strategic Management Journal, 12(4): 281-297.

Datta, D. K., \& Puia, G. (1995). Cross-border acquisitions: an examination of the influence of relatedness and cultural fit on shareholder value creation in US acquiring firms. Management International Review, 35(4), 337-359.

Eisenhardt, K. M., \& Santos, F. M. (2002). Knowledge-based view: A new theory of strategy? In: Pettigrew, A., Thomas, H. and Whittington, R. (eds.), Handbook of Strategy and Management. (pp. 139-164). London: UK: Sage Publications. 
Ellis, K. M., Reus, T. H., Lamont, B. T., \& Ranft, A. L. (2011). Transfer effects in large acquisitions: How size-specific experience matters. Academy of Management Journal, 54(6): 1261-1276.

Empson, L. (2001). Fear of exploitation and fear of contamination: impediments to knowledge transfer in mergers between professional service firms. Human Relations, 54(7): 839-863.

Ernst, H. and Vitt, J. (2000). The influence of corporate acquisitions on the behavior of key inventors. R\&D Management, 30(2): 105-119.

Gomes, E., Angwin, D., Weber, Y., \& Tarba, S. Y. (2013). Critical success factors through the mergers and acquisitions process: Revealing pre- and post- M\&A connections for improved performance. Thunderbird International Business Review, 55(1): 13-35.

Gomes, E., Weber, Y., Brown, C., \& Tarba, S.Y. (2011). Mergers, acquisitions and strategic alliances: Understanding the process. USA \& UK: Palgrave Macmillan.

Graham, J. R. and Harvey, C. R. (2001). The theory and practice of corporate finance: Evidence from the field. Journal of Financial Economics, 60(2): 187-243.

Grant, R. M. (1996a). Prospering in dynamically-competitive environments: Organizational capability as knowledge integration. Organization Science, 7(4): 375-387.

Grant, R. M. (1996b). Toward a knowledge-based theory of the firm. Strategic Management Journal, 17: 109-122.

Gupta, A. K. and Govindarajan, V. (2000). Knowledge flows within multinational corporations. Strategic Management Journal, 21(4): 473-496.

Hambrick, D. C., \& Cannella Jr, A. A. (1993). Relative standing: A framework for understanding departures of acquired executives. Academy of Management Journal, 36(4): 733762.

Hansen, M. T. (1999). The search-transfer problem: The role of weak ties in sharing knowledge across organization subunits. Administrative Science Quarterly, 44(1): 82-112.

Harzing, A. (1997). Response rates in international mail surveys: Results of a 22 country study. International Business Review, 6(6): 641-665.

Hebert, L., Very, P., \& Beamish, P. W. (2005). Expatriation as a bridge over troubled water: A knowledge-based perspective applied to cross-border acquisitions. Organization Studies, 26(10): 1455-1476.

Hennart, J.-F., \& Park, Y. R. (1993). Greenfield vs. acquisition: The strategy of Japanese investors in the United States. Management Science, 39(9): 1054-1070.

Holtbrügge, D., \& Mohr, A. T. (2010). Cultural determinants of learning style preferences. Academy of Management Learning \& Education, 9(4): 622-637.

Hoopes, D. G. and Postrel, S. (1999). Shared knowledge, "glitches," and product development performance. Strategic Management Journal, 20(9): 837-865.

House, R. J., Hanges, P. J., Javidan, M., Dorfman, P. W. and Gupta, V. (2004). Culture, leadership and organisations: The GLOBE study of 62 societies, Thousand Oaks: Sage.

Huber, G. P. (1991). Organizational learning: The contributing processes and the literatures. Organization Science, 2(1): 88-115. 
Hymer, S. (1976). International operations of national firms: A study of direct investment, Cambridge, MA: MIT Press.

Jansen, J. J. P., Van Den Bosch, F. A. J., \& Volberda, H. W. (2005). Managing potential and realized absorptive capacity: How do organizational antecedents matter? Academy of Management Journal, 48(6): 999-1015.

Jensen, R., \& Szulanski, G. (2004). Stickiness and the adaptation of organizational practices in cross-border knowledge transfers. Journal of International Business Studies, 35: 508-523.

Junni, P. (2011). Knowledge transfer in acquisitions: Fear of exploitation and contamination. Scandinavian Journal of Management, 27(3): 307-321.

Junni, P., \& Sarala, R. M. (2011). Causal ambiguity, partner attractiveness, and cultural integration as determinants of knowledge transfer: Evidence from Finnish acquisitions. European Journal of International Management, 5: 346-372.

Junni, P., \& Sarala, R.M. (2012). The role of cultural learning and collective teaching initiatives in M\&A knowledge transfer. European Journal of Cross-Cultural Competence and Management, 2(3): 275-298.

Junni, P., \& Sarala, R.M. (2013). The role of absorptive capacity in acquisition knowledge transfer. Thunderbird International Business Review, 55(4): 419-438.

Junni, P., Sarala, R., \& Vaara, E. (2013). Knowledge transfer in M\&As: An integrative framework and future research agenda. In: Handbook for Mergers and Acquisitions Research, (Ed. Yaakov Weber), Edward Elgar Ltd.: UK.

Kirkman, B. L., Lowe, K. B., \& Gibson, C. B. (2006). A quarter century of Culture's Consequences: A review of empirical research incorporating Hofstede's cultural values framework. Journal of International Business Studies, 37(3): 285-320.

Kitching, J. (1967). Why do mergers miscarry? Harvard Business Review, 45(6): 84-107.

Kogut, B., \& Zander, U. (1992). Knowledge of the firm, combinative capabilities, and the replication of technology. Organization Science, 3(3): 383-397.

Kogut, B., \& Zander, U. (1993). Knowledge of the firm and the evolutionary theory of the multinational corporation. Journal of International Business Studies, 24(4): 625-645.

Krug, J. A. (2003). Executive turnover in acquired firms: A longitudinal analysis of long term integration effects. Paper presented at the Academy of Management Meeting. August 1-6, 2003. Seatle, Washington: USA.

Krug, J. A., \& Hegarty, W. H. (1997). Post-acquisition turnover among U.S. top management teams: an analysis of the effects of foreign vs. domestic acquisitions of U.S. targets. Strategic Management Journal, 18(8): 667-675.

Krug, J.A., \& Hegarty, W.H. (2001). Predicting who stays and leaves after an acquisition: a study of top managers in multinational firms. Strategic Management Journal, 22(2): 185-196.

Krug, J., Wright, P., \& Kroll, M. (2014). Top management turnover following mergers and acquisitions: Solid research to date but much still to be learned. Academy of Management Perspectives, 28(2): 147-163.

Lakshman, C. (2011). Post-acquisition cultural integration in mergers and acquisitions: A knowledge-based approach. Human Resource Management, 50(5): 605-623. 
Lane, P. J., Koka, B. R., \& Pathak, S. (2006). The reification of absorptive capacity: A critical review and rejuvenation of the construct. Academy of Management Review, 31(4): 833-863.

Larsson, R. and Finkelstein, S. (1999). Integrating strategic, organisational, and human resource perspectives on mergers and acquisitions: A case survey of synergy realization. Organization Science, 10(1): 1-26.

Larsson, R. and Risberg, A. (1998). Cultural awareness and national versus corporate barriers to acculturation. In: Gertsen, M. C., Soderberg, A-M. and Torp, J. E. (eds.), Cultural dimensions of international mergers and acquisitions. Berlin: De Gruyter.

Larsson, R., \& Lubatkin, M. (2001). Achieving acculturation in mergers and acquisitions: An international case survey. Human Relations, 54(12): 1573-1607.

Leonard, D. 1998. Wellsprings of knowledge: Building and sustaining the sources of innovation. Boston, MA: Harvard Business Press.

Liu, Y., \& Woywode, M. 2013. Light-touch integration of Chinese cross-border M\&A: The influences of culture and absorptive capacity. Thunderbird International Business Review, 55 (4): 469-483.

Lubatkin, M., Schweiger, D. and Weber, Y. 1999. Top management turnover in related M\&A's: An additional test of the theory of relative standing. Journal of Management, 25, No. 1, 55-73.

Morosini, P., Shane, S., \& Singh, H. 1998. National cultural distance and cross-border acquisition performance. Journal of International Business Studies, 29(1): 137-158.

Mukherjee, T. K., Kiymaz, H. and Baker, H. K. 2004. Merger motives and target valuation: A survey of evidence from CFOs. Journal of Applied Finance, Fall/Winter, 7-24.

Nelson, R. R., \& Winter, S. G. 1982. An evolutionary theory of economic change. Cambridge, MA: Harvard University Press.

Neter, J., Wasserman, W. and Kutner, M. H. 1985. Applied linear statistical models: Regression, analysis of variance, and experimental design, Homewood, IL: Irwin.

Nonaka, I. 1994. A dynamic theory of organizational knowledge creation. Organization science, 5(1): 14-37.

Nonaka, I., \& Takeuchi, H. 1995. The knowledge-creating company: How Japanese companies create the dynamics of innovation. Oxford Oxford University Press.

Nonaka, I., Toyama, R., \& Nagata, A. 2000. A firm as a knowledge - creating entity: A new perspective on the theory of the firm. Industrial and Corporate Change, 9 (1): 1-20.

Öberg, C., and Tarba, S.Y. (2013). What do we know about post-merger integration following international acquisitions? Advances in International Management, 26: 469-492.

Olie, R. 1994. Shades of culture and institutions in international mergers. Organization Studies, 15, No. 3, 381-405.

Podsakoff, P. M., Mackenzie, S. B., Lee, J. and Podsakoff, N. P. 2003. Common method biases in behavioural research: A critical review of the literature and recommended remedies. Journal of Applied Psychology, 88, No. 5, 879-903.

Poppo, L., Zhou, K. Z., and Sungmin, R. 2008. Alternative origins to interorganizational trust: An interdependence perspective on the shadow of the past and the shadow of the future. Organization Science, 19, No. 1, 39-55. 
Prahalad, C. K., \& Hamel, G. 1990. The core competence of the corporation. Harvard Business Review, 68: 79-91.

Preacher, K. J., and Hayes, A. F. 2008. Asymptotic and re-sampling strategies for assessing and comparing indirect effects in multiple mediator models. Behavior Research Methods, 40, No. 3 , 879-891.

Ranft, A. 2006. Knowledge preservation and transfer during post - acquisition integration. Advances in Mergers and Acquisitions, 5, 51-67.

Ranft, A. L. 1997. Preserving and transferring knowledge-based resources during post acquisition implementation. PhD Thesis. University of North Carolina, Chapel Hill, NC, USA.

Ranft, A. L. (2006). Knowledge preservation and transfer during post-acquisition integration. In C. L. Cooper, \& S. Finkelstein (Eds.), Advances in Mergers \& Acquisitions, Vol. 5: 51-67: Emerald Publishing Group.

Ranft, A. L., \& Lord, M. D. (2000). Acquiring new knowledge: the role of retaining human capital in acquisitions of high-tech firms. The Journal of High Technology Management Research, 11(2): 295-319.

Ranft, A. L., \& Lord, M. D. (2002). Acquiring new technologies and capabilities: A grounded model of acquisition implementation. Organization Science, 13(4): 420-441.

Reus, T. H. (2012). A knowledge-based view of mergers and acquisitions revisited: Absorptive capacity and combinative capability. Advances in Mergers and Acquisitions, 11: 69-88.

Reus, T. H., \& Lamont, B. T. (2009). The double-edged sword of cultural distance in international acquisitions. Journal of International Business Studies, 40(8): 1298-1316.

Riad, S., Vaara, E., \& Zhang, N. (2012). The intertextual production of international relations in mergers and acquisitions. Organization Studies, 33(1): 121-148.

Rottig, D., Reus, T. H., \& Tarba, S. Y. (2013). The impact of culture on mergers and acquisitions: A third of a century of research. Advances in Mergers and Acquisitions, 12: 135172.

Sales, A. L., \& Mirvis, P. H. 1985. When cultures collide: Issues in acquisition. In: Kimberley, J. R. and Quinn, R. E. (eds.), New futures: The challenge of managing organizational transition. IL: Irwin.

Sarala, R. M. (2010). The impact of cultural differences and acculturation factors on postacquisition conflict. Scandinavian Journal of Management, 26(1): 38-56.

Sarala, R. M., \& Vaara, E. (2010). Cultural differences, convergence, and crossvergence as explanations of knowledge transfer in international acquisitions. Journal of International Business Studies, 41(8): 1365-1390.

Sarala, R. M., Junni, P., Cooper, C. L., \& Tarba, S. Y. (2014). A sociocultural perspective on knowledge transfer in mergers and acquisitions. Journal of Management, (Forthcoming, doi: 0149206314530167).

Schoenberg, R. (2001). Knowledge transfer and resource sharing as value creation mechanisms in inbound continental European acquisitions. Journal of Euromarketing, 10(1): 99-114. 
Schoenberg, R. (2004). Dimensions of management style compatibility and cross-border acquisition outcome. In: Cooper, C. and Finkelstein, S. (eds.), Advances in Mergers and Acquisitions, 3: 149-175.

Schweiger, D. M., \& Denisi, A. S. (1991). Communication with employees following a merger A longitudinal field experiment. Academy of Management Journal, 34(1): 110-135.

Schweiger, D. M., \& Goulet, P. K. (2005). Facilitating acquisition integration through deep-level cultural learning interventions: A longitudinal field experiment. Organization Studies, 26(10): 1477-1499.

Schweizer, L. (2005). Knowledge transfer and R\&D in pharmaceutical companies: a case study. Journal of Engineering and Technology Management, 22(4): 315-331.

Slangen, A. H. L.(2006). National cultural distance and initial foreign acquisition performance: The moderating effect of integration. Journal of World Business, 41: 161-170.

Stahl, G., \& Voigt, A. (2008). Do cultural differences matter in mergers and acquisitions? A tentative model and examination. Organization Science, 19(1): 160-176.

Stahl, K. and Voigt, A. 2005. Impact of cultural differences on mergers and acquisitions performance: A critical research review and an integrative model. Advances in Mergers and Acquisitions, 4, 51-83.

Stahl, K.G., Mendenhall, M.E. \& Weber, Y. 2005. Research on sociocultural integration in mergers and acquisitions: Points of agreement, paradoxes, and avenues for future research. In G. K. Stahl \& M. E. Mendenhall (Eds.), Mergers and acquisitions: Managing culture and human resources (pp. 401-411). Stanford, CA: Stanford University Press.

Stahl, G. K., Angwin, D. N., Very, P., Gomes, E., Weber, Y., Tarba, S. Y., Noorderhaven, N., Benyamini, H., Bouckenooghe, D., Chreim, S., Durand, M., Hassett, M. E., Kokk, G., Mendenhall, M. E., Mirc N., Miska, C., Park, K. M., Reynolds, N-S., Rouzies, A., Sarala, R. M, Soloti Jr., S. L., Søndergaard, M., \& Yildiz, H. E. 2013. Sociocultural integration in mergers and acquisitions: Unresolved paradoxes and directions for future research. Thunderbird International Business Review, 55(4): 333-356.

Sternberg, R. J., \& Horvath, J. A. 1999. Tacit knowledge in professional practice: Researcher and practitioner perspectives. Mahwah, NJ: Lawrence Erlbaum.

Szulanski, G. 1996. Exploring internal stickiness: Impediments to the transfer of best practice within the firm. Strategic Management Journal, 17(special issue): 27-43.

Szulanski, G., \& Jensen, R.J. 2006. Presumptive adaptation and the effectiveness of knowledge transfer.Strategic Management Journal, 27, 937-957.

Szulanski, G., Cappetta, R., \& Jensen R.J. 2004. When and how trustworthiness matters: knowledge transfer and the moderating effect of causal ambiguity. Organization Science, 15(5), 600-613.

Teerikangas, S. and Very, P. 2006. The culture-performance relationship in M\&A: From Yes/No to how. British Journal of Management, 17, S31-S48.

Tsai, W. 2001. Knowledge transfer in intra-organizational networks: Effects of network position and absorptive capacity on business unit innovation and performance. Academy of Management Journal, 44(5): 996-1004. 
Uhlenbruck, K. (2004). Developing acquired foreign subsidiaries: the experience of MNEs in transition economies. Journal of International Business Studies, 35: 109-123.

Vaara, E., Sarala, R., Stahl, G. K., \& Björkman, I. 2012. The impact of organizational and national cultural differences on social conflict and knowledge transfer in international acquisitions. Journal of Management Studies, 49(1): 1-27.

Van Wijk, R., Jansen, J. J. P., \& Lyles, M. A. 2008. Inter-and intra-organizational knowledge transfer: A meta-analytic review and assessment of its antecedents and consequences. Journal of Management Studies, 45(4): 830-853.

Veiga, J., Lubatkin, M., Calori, R., and Very, P. 2000. Measuring organizational culture clashes: A two-nation post-hoc analysis of a cultural compatibility index. Human Relations, 53, No. 4, 539-557.

Verbeke, A. 2010. International acquisition success: Social community and dominant logic dimensions. Journal of International Business Studies, 41(1): 38-46.

Vermeulen, F., \& Barkema, H. 2001. Learning through acquisitions. Academy of Management Journal: 457-476.

Very, P., Lubatkin, M., Calori, R., and Veiga, J. 1997. Relative standing and the performance of recently acquired European firms. Strategic Management Journal, 18, No. 8, 93-614.

Villinger, R. 1996. Post-acquisition managerial learning in Central East Europe. Organization Studies, 17, No 2, 181-206.

Volberda, H. W., Foss, N. J., \& Lyles, M. A. 2010. Absorbing the concept of absorptive capacity: How to realize its potential in the organization field. Organization Science, 21(4): 931951.

Walsh, J. P. 1988. Top management turnover following mergers and acquisitions. Strategic Management Journal, 9 (2): 173-183.

Walsh, J. P. 1989. Doing a deal: Merger and acquisition negotiations and their impact upon target company top management turnover. Strategic Management Journal, 10(4): 307-322.

Walsh, J. P. and Ellwood, J. W. 1991. Mergers, acquisitions, and the pruning of managerial deadwood. Strategic Management Journal, 12, No. 3, 201-217.

Weber, Y. 1996. Corporate cultural fit and performance in mergers and acquisitions. Human relations, 49(9): 1181-1202.

Weber, Y. \& Fried, Y. (2011a). The role of HR practices in managing culture clash during the post merger integration process. Human Resource Management, 50(5): 565-570.

Weber, Y. \& Fried, Y. (2011b). The dynamic of employees' reactions during post merger integration process. Human Resource Management, 50(6): 777-781.

Weber, Y., \& Tarba, S. Y. (2010). Human resource practices and performance of mergers and acquisitions in Israel. Human Resource Management Review, 20(3): 203-211.

Weber, Y., \& Tarba, S.Y. (2012). Mergers and acquisitions process: The use of corporate culture analysis. Cross-Cultural Management: An International Journal, 19(3): 288-303. 
Weber, Y., Tarba, S. Y., \& Öberg, C. (2014). A comprehensive guide to mergers \& acquisitions: Managing the critical success factors across every stage of the M\&A Process. New York London: Pearson\& Financial Times Press.

Weber, Y., Rachman-Moore, D., \& Tarba, S. Y. 2011. HR practices during post-merger conflict and merger performance. International Journal of Cross-Cultural Management, 12(1): 73--99.

Weber, Y., Shenkar, O. and Raveh, A. 1996. National and corporate cultural fit in mergers/acquisitions: An exploratory study. Management Science, 42, No. 8, 1215-1227.

Weber, Y., Tarba, S. Y., \& Rozen Bachar, Z. 2011. Mergers and acquisitions performance paradox: the mediating role of integration approach. European Journal of International Management, 5(4): 373-393.

Weber, Y., Tarba, S. Y., \& Rozen Bachar, Z. R. (2012). The effects of culture clash on international mergers in the high tech industry. World Review of Entrepreneurship, Management and Sustainable Development, 8(1): 103-118.

Weber, Y., Tarba, S. Y., Stahl, G.K., \& Rozen Bachar, Z. (2012). Integration of international mergers and acquisitions: A test of new integration approach paradigm. In Y. Weber (Ed.). Handbook on Mergers and Acquisitions Research. UK: Edward Elgar.

Weber, Y., Tarba, S.Y., \& Reichel, A. (2009). International mergers and acquisitions performance revisited - The role of cultural distance and post-acquisition integration approach implementation. Advances In Mergers and Acquisitions, 8, 1-18.

Weber, Y., Tarba, S.Y., \& Reichel, A. (2011). A model of the influence of culture on integration approaches and international mergers and acquisitions performance. International Studies of Management and Organization, 41(3), 9-24.

Woodcock, C. P., Beamish, P. W., \& Makino, S. (1994). Ownership-based entry mode strategies and international performance. Journal of International Business Studies, 25(2): 253-273.

Zahra, S. A., \& George, G. (2002). Absorptive capacity: A review, reconceptualization, and extension. Academy of Management Review, 27(2): 185-203.

Zander, U., \& Zander, L. (2010). Opening the grey box: Social communities, knowledge and culture in acquisitions. Journal of International Business Studies, 41(1): 27-37.

Zollo, M. \& Singh, H. (1998). The impact of knowledge codification: experience trajectories and integration strategies on the performance of corporate acquisitions. Paper presented at Academy of Management Annual Meeting: What matters most. August 7-13, 1998. San Diego, CA, USA.

Zollo, M., \& Singh, H. (2004). Deliberate learning in corporate acquisitions: post-acquisition strategies and integration capability in US bank mergers. Strategic Management Journal, 25(13): 1233-1256.

Zou, H., \& Ghauri, P. N. (2008). Learning through international acquisitions: The process of knowledge acquisition in China. Management International Review, 48(2): 207-226. 